\title{
SCHOLASTINĖ LOGIKA LIETUVOJE: STRUKTŪRA, OBJEKTAS IR FORMA
}

\author{
Scholastic Logic in Lithuania: Structure, Object and Form
}

\begin{abstract}
SUMMARY
This text continues a cycle of articles devoted to general topics of scholastic logic in Lithuania. The first article of the cycle (Valatka 2020) investigated the beginning of the above mentioned logic and analyzed the its method and argumentation technique. This article, in turn, analyzes structure, object and form of scholastic logic in Lithuania. The author of the article concentrates on the object of the parts of this logic, namely, minor logic, or dialectics, and major logic. The article comes to conclusion that both dialectics and major logic regarded three operations of human intellect (apprehension, proposition and reasoning) as its proper object. Dialectics was interested in the forms of these operations; therefore this part of scholastic logic can be considered a certain equivalent of modern formal logic. Meanwhile, major logic concentrated on contents of those operations. Hence, we can understand it as the scholastic theory of cognition. The article also concludes that works of scholastic logic in Lithuania were not independent and authentic texts. Due to role of authorities in scholastic method, treatises, manuals, logic courses were commentaries on the treatises of Aristotle and the other authorities of scholastic logic in the spirit of certain scholastic trends or even eclecticism.
\end{abstract}

\section{SANTRAUKA}

Šis tekstas pratęsia ciklą straipsnių, skirtų bendrajai scholastinės logikos Lietuvoje problematikai. Pirmajame ciklo straipsnyje (Valatka 2020) nagrinètas šios logikos pradžios klausimas, jos tyrimo metodas ir taikoma irodinejjimo technika. Šiame straipsnyje analizuojama scholastinės logikos Lietuvoje struktūra, objektas ir forma. Straipsnio autorius susitelkia ties šios logikos dalių - mažosios logikos, arba dialektikos, ir didžiosios logikos - objektu. Prieinama prie išvados, kad tiek dialektika, tiek didžioji logika savo objektu laikè tris žmogiškojo mąstymo veiksmus: sąvokinį supratimą, teiginį ir samprotavimą. Dialektiką domino šių veiksmų forma, todèl ji laikytina tam tikru šiuolaikinès formaliosios logikos atitikmeniu. O didžioji logika susitelkè 
ties minėtų veiksmų turiniu, todèl ją galime laikyti scholastine pažinimo teorija. Taip pat tvirtinama, kad scholastinès logikos Lietuvoje autorių kūriniai nebuvo savarankiški ir autentiški tekstai. Dèl scholastinio metodo autoritarizmo šios logikos traktatai, vadovèliai ir paskaitų kursai buvo įvairių scholastikos srovių ar netgi eklektizmo pateikiami Aristotelio ir kitu scholastinès logikos autoritetų traktatų komentarai.

\section{IVADAS}

Išnagrinëjus Lietuvos scholastinëje logikoje taikytą metodologija, natūralu pereiti prie šios logikos tyrimo objekto. Vis dèlto išsami jo analizè neįmanoma neišnagrinejjus pačios scholastinès logikos struktūros. Juk kiekvieną mokslą sudaro bent keletas teoriju, dalių, disciplinų ir pan. Kiekviena šių teoriju, dalių ar disciplinų turi atskira, jos specifiką atitinkanti (aristoteline kalba kalbant, rūšinį) objekta, tiesa, kartu išlaiko bendrąsias (t. y. giminines) konkretaus mokslo bendrojo objekto charakteristikas. Scholastinè logika Lietuvoje taip pat nelaikytina jokia išmintimi. Kaip ir visa tuomete europinè scholastinè logika, ji susidejo iš dviejų disciplinų: mažosios logikos, arba dialektikos (logica minor sive dialectica), ir didžiosios logikos (logica maior), arba tiesiog logikos (logica). Tokią scholastinès logikos struktūrą puikiai iliustruoja Vilniaus universiteto profesoriaus Jokūbo Ortizo (Diego Ortiz, Iacob Ortizius) 1596$1597 \mathrm{~m}$. universitete skaitytas logikos paskaitu kursas (Ortizius, 1596-1597), kuris susideda iš dialektinès dalies (In universam Aristotelis Logicam Summula) ir didžiajai logikai priskiriamos dalies (In universam Aristotelis logicam commentarii cum questionibus) ${ }^{1}$.

\section{MAŽOSIOS LOGIKOS, ARBA DIALEKTIKOS, OBJEKTAS}

Kaip jau minèta, pirmoji scholastinès logikos disciplina buvo dialektika. Ji iš esmès buvo taisyklingo mąstymo teorija. Ją galime laikyti tam tikru šiuolaikinès logikos atitikmeniu, nes jos objektas buvo ne kas kita, kaip protavimo, arba loginè minties forma (Plečkaitis 2004: 319). Dar tiksliau kalbant, dialektika analizavo tris žmogiškojo mąstymo veiksmus - sąvokini supratimą (apprehensio), sprendini, arba teigini (judicium sive propositio), bei samprotavimą arba silogizmą (discursus sive syllogismus), susitelkdama ties šiu mąstymo operacijų forma. Čia buvo aiškinami bendrieji sąvokų, terminu, teiginiu, samprotavimu, apibrè- žimų, skirstymų etc. principai; mokoma, kaip iš vienu teiginių taisyklingai gauti kitus ir t. t. Tokiu būdu dialektikai buvo būdinga grynai loginè problematika, nes šiuolaikinis logikos mokslas savo objektu laiko būtent mąstymo formą.

Būtina pabrěžti, kad scholastinè dialektika buvo aukšto lygio loginè sistema. Tiesa, ši scholastinès logikos dalis dar netaikè formalizavimo metodo, kitaip sakant, loginès simbolikos. Būtent teiginiai, samprotavimai, logikos dèsniai bei kitos loginès išraiškos dialektikoje turèjo îprastos šnekamosios kalbos pavidalą. Vis dèlto net ir nenaudodami formalizavimo metodo scholastinès logikos kū- 
rèjai pasiekè solidžių rezultatų. Štai vienas žymiausiu Lietuvos filosofijos istorijos tyrinètoju prof. Romanas Plečkaitis, remdamasis Vilniaus universiteto profesoriu Čirskio (Czyrski, 1668-1669), Kriugerio (Kruger, 1701-1702) ir kitais universitete skaitytais dialektikos kur- sais, įrodè, kad scholastinè dialektika tai šiuolaikinès formaliosios logikos teorijų (teiginių logikos, loginių klasių teorijos, modalinès logikos, loginès sekos teorijos, semiotikos ir loginès semantikos) užuomazgos (Plečkaitis 1976: 112; Plečkaitis 2004: 320).

\section{INTELEKTO PIRMOJO VEIKSMO AIŠKINIMAS DIDŽIOJOJE LOGIKOJE}

Antrosios scholastinès logikos dalies - didžiosios logikos, arba tiesiog logikos, - objektas taip pat buvo trys žmogiškojo mąstymo veiksmai. Ši disciplina taip pat sieke suformuluoti taisykles, kuriomis remdamasis žmogiškasis mąstymas galètu pasiekti savajij tikslą, tai yra atrasti tiesą. Tačiau didžioji logika minètas mąstymo operacijas tyrė kiek kitu aspektu nei dialektika. Pastaroji susitelkè ties žmogiškojo mąstymo forma, o didžioji logika daugiausia dèmesio skyrè šio mąstymo turiniui. Pirmoji siekè atrasti taisyklingo mąstymo dèsnius, o antroji pretendavo pateikti teisingo mąstymo principus ir taisykles. Tad didžiają logiką turètume laikyti scholastine pažinimo teorija, tyrusia bendruosius pažinimo principus kaip esmingiausius pažintinio turinio dèsningumus.

Aiškindama pirmąji mąstymo veiksmą, didžioji logika rẻmėsi bendruju daiktiniu prigimčiu - universaliju (universalia) - teorija. Šios teorijos pagrindu buvo irodinejjama, kad sąvokinio suvokimo, lygiai kaip ir intelektinio pažinimo pirminis objektas yra būtent minètosios universalijos. Taip pat čia buvo diskutuojama, ar universalijos yra realios būtys (entia realia), ar, atvirkščiai, joms galime priskirti tik proto esiniu (entia realia) statusa; analizuojamos esminès universaliju savybės ir $t$. $t$. Pati universaliju teorija buvo papildoma vadinamujju Porfirijo penkiu žodžių, arba predikabiliu (praedicabilia), bei Aristotelio kategoriju, arba predikamentu (praedicamenta), aptarimu. Svarbu pažymèti, kad predikabiliai ir predikamentai čia turèjo bendriausiu universalijos giminiu statusa, kitaip sakant, jie buvo suprantami kaip bendriausios sąvokos, kuriomis privalo vykti tiek sąvokinis, tiek ir bet kuris kitas intelektinis bet kurios būties pažinimas². Tad žmogaus intelekto pirmojo veiksmo interpretacijoje didžioji logika susitelkè ties šio veiksmo turiniu ${ }^{3}$.

Kita vertus, negalima paneigti ir glaudaus didžiosios logikos ryšio su dialektika - šios dėsniai didžiojoje logikoje buvo taikomi nustatant santykius tarp predikabilių ir kategorijų. Štai siekdami irodyti predikavimo santykị tarp giminès ir rūšies predikabiliu, didžiosios logikos kūrèjai samprotaudavo šitaip: „Tas, kas egzistuoja kame nors kitame kaip pastarojo esmė, yra ir tam kitam priskiriamas kaip jo esmè. O giminė egzistuoja rūšyse kaip jų esmè. Vadinasi, giminė predikuojama rūšims kaip ju esmè" (Smiglecius 1987: 71). Akivaizdu, kad tokia išvada 
buvo gaunama taikant pirmosios silogizmo figūros pirmaji modusą (BARBARA), kuris scholastineje dialektikoje buvo ži- nomas šiuo bendruoju pavidalu: „Kiekvienas $A$ yra $B$; kiekvienas $C$ yra $A$; vadinasi, kiekvienas $\mathrm{C}$ yra B."

\section{INTELEKTO ANTROJO IR TREČIOJO VEIKSMO INTERPRETACIJA DIDŽIOJOJE LOGIKOJE}

Aptardama pirmajji mąstymo veiksma, didžioji logika daugiausia dèmesio skyrè jo turiniui, o antrosios ir trečiosios intelekto operacijos analizejje buvo šiek tiek grižtama ir prie šiu operaciju formos. Mat kaip ir dialektikoje, didžiojoje logikoje buvo pateikiami loginio kvadrato desniai, pagal kuriuos skirtingas logines jungtis turintys sudètiniai teiginiai (konjunkcijos, disjunkcijos etc.) ir jų neiginiai išvedami vienas iš kito bei pakeičiami lygiavertemis išraiškomis. Lygiai kaip ir dialektikoje, didžiojoje logikoje kalbèta apie taisyklingas silogizmo figūras ir modusus. Tačiau net ir antrojo bei trečiojo intelekto veiksmų tyrime didžioji logika susitelkè ties šių operaciju turi$\mathrm{niu}^{4}$. Štai analizuodama teiginio prigimtí, logika daug vietos skyrè jo sudedamuju daliu - daiktavardžio (nomen) ir veiksmažodžio (verbum) - reikšmès klausimui. Tiksliau kalbant, siekta išsiaiškinti, kokia reikšmẻ būdinga šiems teiginio elementams, juos imant skyriumi, ir kaip ji pasikeičia, jiems susijungus $i$ teigini. Antrojo intelekto veiksmo analizèje didžioji logika daugiausia dèmesio skyrè ne teiginiams kaip tokiems, o būtiniems teiginiams (propositiones necessariae), tai yra visada teisingiems teiginiams, būtent tokius teiginius laikydama bet kurio į moksliškumą pretenduojančio pažinimo dalimis. Aptariant būtinus teiginius buvo analizuojami būtini šiu teiginių kriterijai; siekta atsakyti i klausimą, ar tam, kad koks nors teiginys taptu visuotine tiesa, greta kitu sąlygų būtina ir reali to teiginio objekto egzistencija etc.

Trečiojo mąstymo veiksmo analizę didžioji logika paprastai taip pat pradèdavo grynai epistemologiniu klausimu. Pastarojo pagrindu buvo bandoma išsiaiškinti, ar, kaip mano Platonas, diskursyvaus, tai yra silogistinio, pažinimo turinys yra kadaise jau igyto pažinimo turinio anamnezè, ar, priešingai, diskursyvus pažinimas - tai visiškai naujas pažinimo etapas, išvedamas iš anksčiau igytojo pažinimo. Tada, aptarusi esminius samprotavimo požymius, didžioji logika susitelkdavo ties viena silogizmo rūšiu - įrodymu. Būtent šis įrodomasis silogizmas, susidedantis iš būtinu, tai yra visada teisingų teiginiu, scholastineje logikoje turëjo svarbiausios samprotavimo rūšies statusą. Mat scholastinè logika būtent ši silogizmą laikẻ tokiu pažinimo irankiu, kurio rezultatas yra mokslinis pažinimas (scientia). Šis taip pat buvo plačiai aptariamas didžiojoje logikoje, todèl galima tvirtinti, jog ši logika aprèpé ir tam tikrą bendrajją mokslo teoriją. Ši scholastinè mokslinio pažinimo teorija analizavo mokslo santyki su tikejjimu, nuomone ir kitomis žmogiškojo pažinimo formomis, nagrinèjo juslinio patyrimo (experientia) ir patyriminio stebèjimo (experimentum) vaidmeni mokslinio pažinimo procese, pateikè išplèstą aristotelinę mokslų klasifikaciją ir t. t. Tad aki- 
vaizdu, kad nors didžioji logika ir susidurdavo su grynai logine problematika, vis dèlto svarbiausią vietą čia užèmè epistemologiniai ir filosofiniai mąstomosios veiklos klausimai. Būtent dèl to ši antroji scholastinès logikos disciplina buvo vadinama ne tik didžiąja logika, bet ir proto filosofija (philosophia rationalis).

Taigi tiek dialektika, tiek ir didžioji logika, arba proto filosofija, savo objektu laikè tris žmogiškojo intelekto veiksmus. Tiesa, pirmąją discipliną domino šių veiksmų forma, o antroji disciplina daugiausia dèmesio sutelkè i minètų veiksmų turinị. Bet vis dèlto abi scholastinès logikos disciplinos siekẻ to paties tikslo, tai yra pateikti žmogiškajam mąstymui griežtas, aiškias ir tikslias taisykles, kurių vedamas jis galètų pasiekti aiškų, tikslų ir tikra, kitaip sakant, mokslini Dievo ir jo sukurto pasaulio pažinimą. Tokiu bū$\mathrm{du}$ formuluodama taisyklingo mąstymo (mąstymo formos) ir teisingo mąstymo (mąstymo turinio) taisykles kaip bendrąsias ir būtinas mokslinio pažinimo sąlygas, logika buvo bendrasis scholastiniu mokslų irankis, kurio pagrindu plètojosi visi minètieji mokslai: metafizika, gamtos filosofija, etika, politine filosofija, socialinè filosofija, teisès filosofija etc.

\section{DIALEKTIKOS IR DIDŽIOSIOS LOGIKOS FORMOS YPATUMAI}

Išanalizavę esmines dialektikos ir didžiosios logikos turinio (objekto) ypatybes pereikime prie šių scholastinès logikos daliu formos aptarimo. Kaip ir kitu scholastiniu mokslų, lygiai taip pat ir scholastinès logikos Lietuvoje autorių kūriniai nebuvo savarankiški ir autentiški. Kitaip sakant, tai nebuvo veikalai, kuriuose autoriai savarankiškai keltų problemas bei hipotezes ir lygiai taip pat savarankiškai ieškotų galimų problemų sprendimu ir hipotezių patvirtinimo. Priežastis čia labai paprasta: dèl scholastinio tyrimo metodo autoritarizmo scholastinès logikos tekstai tegalèjo būti autoritetingų filosofų (ir pirmiausiai Aristotelio) kūrybos komentarai ir tęsiniai. Konkrečiau ir detaliau kalbant, minètų tekstų problematiką nulemdavo komentuojamame veikale nagrinejjamos problemos, o šių problemų sprendimo būdą ir priemones padiktuodavo Katalikų bažnyčios bei konkretaus vienuolių ordino (pranciškonų, dominikonų, jėzuitų ir pan.) aprobuoti autoritetai.

Tokia autoritetingo teksto komentavimo forma buvo privaloma abiem scholastinès logikos dalims. Todèl tiek dialektikos, tiek didžiosios logikos traktatai, vadovèliai ar paskaitų kursai buvo tik „didžiojo mokytojo“ Aristotelio bei mažesnių scholastinès logikos autoritetų Porfirijo, Boecijaus, Gilberto Poretano (Gilbert de la Poree, Gilbertus Pictaviensis), Petro Ispano ir kt. - traktatų komentarai kurių nors scholastikos sroviu (tomizmo, škotizmo, okamizmo, suarizmo etc.) ar netgi eklektizmo dvasia. Štai dialektikos disciplinoje scholastai komentavo ir interpretavo Aristotelio veikalus „Apie aiškinimą", „Pirmoji analitika“, ,Antroji analitika“, ,Topika“, ,Sofistinių argumentų paneigimas" bei Petro Ispano „Logikos sumą“. O didžioji logika, be minètų pirmujų trijų Stagyriečio traktatų bei Petro Ispano „Logikos 
sumos", komentavo ir analizavo to paties Aristotelio „Kategorijas“ ir neoplatoniko Porfirijo "Ivadą", aiškinanti minètąsias kategorijas. Didžiojoje logikoje taip pat buvo aptariamos kai kurios idèjos ir koncepcijos iš Boecijaus traktatu "Apie skirstymą" ir "Apie skirtingybę" bei Poretano "Šešiuc pradų knygos".

\section{IŠVADOS}

Kaip ir visa europinè scholastinè logika, Lietuvoje plètota scholastinè logika susidèjo iš dvieju disciplinų: mažosios logikos, arba dialektikos, ir didžiosios logikos, arba tiesiog logikos. Tiek dialektika, tiek ir didžioji logika savo objektu laikè tris žmogaus intelekto veiksmus: sąvokini supratima, teigini ir samprotavimą. Tiesa, pirmąą discipliną domino šių veiksmų forma, todèl dialektika laikytina tam tikru šiuolaikinès formaliosios logikos atitikmeniu. O antroji scholastinès logikos disciplina daugiausia dèmesio sutelkè i minètų veiksmų turinị. Todèl didžiąją logiką galime laikyti scholastine pažinimo teorija. Kita vertus, abi scholastinès logikos dalys siekė to paties tikslo, tai yra pateikti žmogiškajam mąstymui griežtas, aiškias ir tikslias taisykles, kurių vedamas jis galètų pasiekti aiškų, tikslų ir tikra, kitaip sakant, mokslini pažinimą.

Scholastinejje dialektikoje buvo pateikiami bendrieji sąvoku, terminu, teiginių, samprotavimų, apibrèžimų, skirstymų principai, loginio kvadrato taisyklès, mokoma, kaip iš vienų teiginių taisyklingai išvesti kitus teiginius. Šie principai, taisyklès ir dèsniai laikytini šiuolaikinès formaliosios logikos teorijų (teiginiu logikos, loginių klasių teorijos, modalinès logikos, loginès sekos teorijos, semiotikos ir loginès semantikos) užuomazgomis.

Scholastinè didžioji logika, analizuodama pirmaji intelekto veiksma, dau- giausia dèmesio skyrè bendrosioms daiktu prigimtims, arba universalijoms, laikydama jas pirminiais minèto veiksmo objektais. Čia svarstyta universalijų statuso problema, ju pažinimo procedūros, aptartos esminès universalijų savybès, nagrinètos bendriausios universalijų giminès: 10 Aristotelio kategoriju ir 5 Porfirijo predikabiliai. Nustatant santykius tarp predikabilių ir kategorijų, plačiai remtasi dialektikos dèsniais.

Antrojo intelekto veiksmo - teiginio analizèje didžioji logika susitelkẻ ties šio veiksmo prigimtimi, jo pagrindinèmis sudedamosiomis dalimis (daiktavardžiu ir veiksmažodžiu), esminiais teiginio požymiais bei rūšimis. Daugiausia dèmesio čia buvo skiriama konkrečiai teiginio rūšiai - būtiniems, arba visada teisingiems, teiginiams. Būtent šie teiginiai laikyti mokslinio pažinimo sudedamosiomis dalimis.

Nagrinėdama trečiajij intelekto veiksmą - samprotavima, arba silogizma, didžioji logika susitelkè ties jo kilme, pagrindiniais požymiais bei rūšimis. Daugiausia dèmesio čia buvo skiriama konkrečiai samprotavimo rūšiai - irodymui. Mat scholastinè logika būtent ši iš būtinų teiginių susidedantị silogizmą laikè pažinimo i̇rankiu, kurio rezultatas yra mokslinis pažinimas. Šis didžiojoje logikoje taip pat sulaukè plačios analizès čia nagrinètas mokslo santykis su kitomis žmogiškojo pažinimo formomis, 
juslinio patyrimo vaidmuo mokslinio pažinimo procese; pateikiama praplèsta aristotelinè mokslų klasifikacija ir t. $t$. Tad didžioji logika aprèpe ir tam tikrą mokslo teoriją.

Kaip ir kitu scholastinių mokslų, lygiai taip pat ir scholastinès logikos Lietuvoje autoriu kūriniai nebuvo savaran-

\section{Literatūra}

Czyrski Alexander. 1668-1669. Logikos paskaitos Vilniaus universitete. Vilniaus universiteto biblioteka, rankraštis F3 - 2055.

Kruger Sigismundus. 1701-1702. Logikos paskaitos Vilniaus universitete. Vilniaus universiteto biblioteka, rankraštis F3 - 582.

Ortizius Iacob. 1596-1597. In universam Aristotelis Logicam Summula. In universam Aristotelis logicam commentarii cum questionibus (Vilnae, 1596-1597). Krakow, Biblioteka Jagiellonska, rekopis 2080.

Plečkaitis Romanas. 1975. Feodalizmo laikotarpio filosofija Lietuvoje. Filosofija Lietuvos mokyklose XVIXVIII $a$. I-II dalys. Vilnius: Mintis.

\section{Nuorodos}

1 Tiesa, kai kurie Lietuvos mokyklose skaityti logikos paskaitų kursai apimdavo tik didžiosios logikos problematika, kaip antai, vieno žymiausių scholastinès logikos kūrejjų Abiejų Tautų Respublikoje - Martyno Smigleckio (Marcin Smiglecki, Martinus Smiglecius) - Vilniaus universitete 1586-1587 m. skaitytas logikos kursas (Smiglecius 1987).

2 Išimtis čia buvo suteikiama vien tik dieviškajai būčiai, kuri dèl savo esminès savybès - skaitinio kiški ir autentiški. Dèl scholastinio metodo autoritarizmo šios logikos traktatai, vadovèliai ar paskaitų kursai buvo tik Aristotelio bei mažesnių scholastinès logikos autoritetu - Porfirijo, Boecijaus, Gilberto Poretano, Petro Ispano ir kt. traktatu komentarai kuriu nors scholastikos sroviu ar netgi eklektizmo dvasia.

Plečkaitis Romanas. 2004. Lietuvos filosofijos istorija. I tomas. Viduramžiai - renesansas - naujieji amžiai. Vilnius: Kultūros, filosofijos ir meno institutas. Smiglecius Martinus. 1987. Commentaria in Organum Aristotelis (Vilnae, 1586-1587). Edidit L. Nowak. Warszawa: Akademia teologii jezuickiej, zeszyt 1.

Valatka Vytis. 2017. Logic at Old Vilnius University: an example of the integrative coexistence of different intellectual discourses, Studies in East European Thought 69(2): 131-142.

Valatka Vytis. 2020. Scholastinè logika Lietuvoje: pradžios klausimas ir metodas, Logos-Vilnius 102: 6-13.

vienumo - netilpo į jokios universalijų giminès rèmus.

3 Plačiau apie universalijų teoriją scholastinejje logikoje Lietuvoje žr. Valatka 2017.

4 Tad kaip ir pirmojo mąstymo veiksmo analizèje, lygiai taip pat ir likusių intelekto veiksmu aptarime didžioji logika taikè minètuosius dialektikos dèsnius kaip nuodugnias šių veiksmų turinio nagrinèjimo priemones. 